\title{
The Effect of Kerokan to Liver Function of Hepatitis B Patients
}

\author{
Nur Adiba Hanum, ${ }^{1}$ Ismalayani, ${ }^{1}$ Rahmad Aswin Juliansyah, ${ }^{2}$ Syokumawena, ${ }^{2}$ \\ Marta Pastari, ${ }^{2}$ Hanna Sari Widya Kusuma, ${ }^{3}$ Yukko Arinta ${ }^{3}$ \\ ${ }^{1}$ Dental Nursing Study Program, ${ }^{2}$ Nursing Study Program, \\ Politeknik Kesehatan Kementerian Kesehatan Palembang, Palembang, Indonesia, \\ ${ }^{3}$ Aretha Medika Utama, Biomolecular and Biomedical Research Center, Bandung, Indonesia
}

\begin{abstract}
Kerokan is an alternative therapy done by rubbing and pressing the skin surface using oil and a blunt object. This treatment has a hepatoprotective effect as it increases heme oxygenase-1, an essential enzyme in heme catabolism. In hepatitis B, heme oxygenase-1 plays a vital role to fight oxidative stress. Hence the damage on liver cells can be reduced or even prevented. Damaged cells indicate by the production of aspartate aminotransferase (AST/SGOT) and alanine aminotransferase (ALT/SGPT) enzymes that accumulated in the bloodstream. This study aimed to investigate the effect of kerokan to liver function by analyzing SGOT and SGPT levels in hepatitis B patients. These were an experimental study with a pre-test post-test control group design conducted in the public health center in Palembang in October 2016. Statistical analysis used the unpaired t test and paired. The research subjects were 30 patients with inactive carrier and chronic hepatitis B. The levels of SGOT and SGPT were determined using the IFCC method. The levels of SGOT in control (19.53 $\pm 3.44 \mathrm{U} / \mathrm{L})$ and treatment group $(20.46 \pm 4.53 \mathrm{U} / \mathrm{L}, \Delta=0.93)$ after 24-48 hours were not statistically different $(\mathrm{p}=0.53)$. Also, the levels of SGPT in control $(18.66 \pm 5.40 \mathrm{U} / \mathrm{L})$ and treatment group $(19.80 \pm 9.25 \mathrm{U} / \mathrm{L}, \Delta=1.13)$ after $24-48$ hours were also not statistically different $(\mathrm{p}=0.68)$ as well. In conclusion, the liver cells of inactive carrier and chronic hepatitis B patients were not damaged (necrosis) after kerokan therapy, and the levels of SGOT and SGPT were still in the normal range.
\end{abstract}

Key words: Hepatitis B, kerokan, SGOT, SGPT

\section{Efek Kerokan terhadap Fungsi Hepar Pasien Hepatitis B}

\begin{abstract}
Abstrak
Kerokan merupakan terapi alternatif yang dilakukan dengan menggosok dan menekan permukaan kulit menggunakan minyak dan benda tumpul. Pengobatan ini bersifat hepatoprotektif, yaitu meningkatkan produksi enzim heme oxygenase-1 dalam katabolisme heme. Pada hepatitis $\mathrm{B}$, heme oxygenase-1 berperan penting dalam menangkal radikal bebas sehingga dapat mengurangi atau mencegah kerusakan sel hepar. Kerusakan sel hepar diindikasikan oleh produksi enzim aspartate aminotransferase (AST/SGOT) dan alanine aminotransferase (ALT/ SGPT) yang terakumulasi dalam pembuluh darah. Penelitian ini bertujuan mengetahui pengaruh kerokan pada fungsi hepar dengan menganalisis kadar SGOT dan SGPT pada pasien hepatitis B. Penelitian eksperimental ini menggunakan desain pre-test post-test control group yang dilakukan di puskesmas di Palembang pada Oktober 2016. Analisis statistik menggunakan uji t berpasangan dan tidak berpasangan. Subjek penelitian meliputi 30 pasien inactive carrier dan kronik hepatitis B. Kadar SGOT dan SGPT diukur dengan menggunakan metode IFCC. Kadar SGOT pada kontrol $(19,53 \pm 3,44 \mathrm{U} / \mathrm{L})$ dan grup perlakuan $(20,46 \pm 4,53 \mathrm{U} / \mathrm{L} ; \Delta=0,93)$ setelah $24-48$ jam tidak terdapat perbedaan signifikan $(\mathrm{p}=0,53)$. Selain itu, kadar SGPT pada kontrol $(18,66 \pm 5,40 \mathrm{U} / \mathrm{L})$ dan grup perlakuan $(19,80 \pm 9,25 \mathrm{U} / \mathrm{L} ; \Delta=1,13)$ setelah $24-48$ jam tidak menunjukkan perbedaan signifikan $(\mathrm{p}=0,68)$. Simpulan, sel hepar pada pasien inactive carrier dan kronik hepatitis B tidak mengalami kerusakan setelah terapi kerokan, serta kadar SGOT dan SGPT tetap dalam kondisi normal.
\end{abstract}

Kata kunci: Hepatitis B, kerokan, SGOT, SGPT

Received: 11 January 2018; Revised: 27 March 2019; Accepted: 26 April 2019; Published: 30 April 2019

Correspondence: Hanna Sari Widya Kusuma. Aretha Medika Utama, Biomolecular and Biomedical Research Center. Jln. Babakan Jeruk II No. 9, Bandung 40163, West Java, Indonesia. Phone: (+622) 7235546. Mobile: +6287721732264. E-mail: hannasariwidyaa@ gmail.com 


\section{Introduction}

Kerokan is a traditional healing therapy used by the people in East Asia using "pressingrubbing" technique. Certain parts of the skin surface are rubbed with oil and pressed by using a blunt object until some of the petechiae appear. Petechiae is an indicator of blood-vessel extravasation in subcutaneous tissues. ${ }^{1}$ Kerokan has hepatoprotective activity as it activates heme oxygenase-1.2,3 Physical stress on skin cells and blood vessels as a result of kerokan will induce the increased synthesis of heme oxygenase-1.3.4 Heme oxygenase- 1 is a cytoprotective enzyme that catabolizes heme into the biliverdin, carbon monoxide, and ferritin. ${ }^{5}$ Bilirubin and biliverdin are antioxidants that act as antioxidative stress, but carbon monoxide plays a role in preventing hepatic ischemia and reperfusion injury through the p38 MAP kinase pathway. Meanwhile, ferritin has cytoprotective effects in which it increases the ATPase pump to release $\mathrm{Fe}^{2+}$ from cytosol.., 6

Mechanism of liver cell damage by the hepatitis $B$ virus is initiated by an autoimmune reaction to liver cells infected. Cytotoxic T lymphocyte (CTL) is a specific antibody that damages liver cells infected by hepatitis B virus. The destroyed liver cells lead to necrosis. ${ }^{7}$ Infection of hepatitis B can be acute and chronic. If virus-eliminating process lasts efficiently, the infection can stop. On the contrary, if the process is less efficient, virus infection will persist. The destruction of liver cells that lasts more than six months is called chronic hepatitis B. Chronic hepatitis B is divided into active-chronic hepatitis $\mathrm{B}$ and inactive carrierchronic hepatitis B. In inactive carrier-chronic hepatitis $\mathrm{B}$, the immune response is not sufficient so that necrosis does not occur although virus replication continues to occur. ${ }^{8}$

Based on the statements mentioned above, the researchers were interested in investigating the effect of kerokan on the liver function of hepatitis B patients.

\section{Methods}

It was an experimental study with a pre-test posttest control group design. Statistical analysis used an unpaired t test and paired. ${ }^{9}$ This study conducted on patients coming to the public health centers in Palembang in October 2016. The subject sample size was 30 patients with inactive carrier-chronic hepatitis $\mathrm{B}$, divided into two groups (control had 15 samples and treatment 15 samples). The $\mathrm{C}$ control group was without any treatment. The blood sample was taken twice from this group, the first taken in any time based on the circadian clock, and the second took 24-48 hours after the first sample. The samples had sent to the laboratory for serum glutamic oxaloacetic transaminase (SGOT) and serum glutamate-pyruvate transaminase (SGPT) analysis.

On the other hand, the blood samples of the treatment group also collected twice-first, the subjects prepared for blood collection. After the first sample, the subjects exposed to kerokan therapy, 24-48 hours after the treatment the blood taken for the second time. In this study, kerokan was applied on to whole parts of the back until seen petechiae. ${ }^{1}$ The levels of SGOT and SGPT determined by the International Federation of Clinical Chemistry (IFCC) method.

This research has received a permit from the Health Research Ethics Committee of Politeknik Kesehatan Makassar by ethical approval letter number: 297/KEPK-PTKMKS/X/2016.

\section{Results}

The results of SGOT and SGPT analysis in this study are in Table 1 . Table 1 shows that the highest level difference $(-3.07 \mathrm{U} / \mathrm{L})$ between the levels of initial SGOT and 24-48 hour SGOT found in the control group. On the other hand, the highest level difference $(-2.53 \mathrm{U} / \mathrm{L})$ between the initial SGPT and 24-48 hour SGPT was in the treatment group.

The normality test of SGOT and SGPT levels are in Table 2. The results showed that $\mathrm{p}$ value in all groups higher than 0.05 ( $p>0.05$ ) that means all data in all group normal distributed.

The comparison of SGOT and SGPT levels in the groups by paired $t$ test has described in Table 3. Table 3 showed that $p$ values in both control groups were higher than $0.05(\mathrm{p}>0.05)$. There was no significant difference in SGOT and SGPT levels between those in the initial and after 2448 hours. Table 3 also shows that no significant difference $(\mathrm{p}=0.00)$ in SGPT levels among the treatment group with a mean difference of -2.53 (U/L).

Table 4 shows a comparison of SGOT and SGPT levels between control and treatment group by unpaired $t$ test. Table 4 reveals that $p$ value in all groups was more than 0.05. Statistically, there was no significant difference between control group and treatment group. 
Table 1 Levels of SGOT and SGPT Analysis

\begin{tabular}{|c|c|c|c|c|c|c|}
\hline \multirow[b]{2}{*}{ Groups } & \multicolumn{3}{|c|}{ SGOT } & \multicolumn{3}{|c|}{ SGPT } \\
\hline & $\begin{array}{c}\text { Initial } \\
\text { Mean } \pm \text { SD } \\
(\mathbf{U} / \mathrm{L})\end{array}$ & $\begin{array}{c}\text { 24-48 Hours } \\
\text { Mean } \pm \text { SD } \\
(\mathrm{U} / \mathrm{L})\end{array}$ & $\begin{array}{c}\Delta \\
(\mathrm{U} / \mathrm{L})\end{array}$ & $\begin{array}{c}\text { Initial } \\
\text { Mean } \pm \text { SD } \\
\text { (U/L) }\end{array}$ & $\begin{array}{c}\text { 24-48 Hours } \\
\text { Mean } \pm \text { SD } \\
(\mathrm{U} / \mathrm{L})\end{array}$ & $\underset{(\mathrm{U} / \mathrm{L})}{\Delta}$ \\
\hline Control & $22.60 \pm 5 \cdot 32$ & $19.53 \pm 3.44$ & -3.07 & $21.00 \pm 6.55$ & $18.66 \pm 5.40$ & -2.34 \\
\hline Treatment & $22.20 \pm 6.37$ & $20.46 \pm 4.53$ & -1.74 & $2233 \pm 9.42$ & $19.80 \pm 9.25$ & -2.53 \\
\hline
\end{tabular}

Table 2 Normality Test of SGOT and SGPT Levels in Control and Treatment Group

\begin{tabular}{lcccc}
\hline \multirow{2}{*}{ Groups } & \multicolumn{2}{c}{ SGOT } & \multicolumn{2}{c}{ SGPT } \\
\cline { 2 - 5 } & Mean \pm SD (U/L) & p Value & Mean \pm SD (U/L) & p Value \\
\hline Control & & & & \\
Initial & $22.60 \pm 5.32$ & 0.92 & $21.00 \pm 6.55$ & 0.83 \\
$\quad 24-48$ hours & $19.53 \pm 3.44$ & 0.72 & $18.66 \pm 5.40$ & 0.45 \\
Treatment & & & & \\
$\quad$ Initial & $22.20 \pm 6.37$ & 0.80 & $22.33 \pm 9.42$ & 0.31 \\
$24-48$ hours & $20.46 \pm 4.53$ & 0.67 & $19.80 \pm 9.25$ & 0.17 \\
\hline
\end{tabular}

Normality test with Kolmogorov-Smirnov test $\mathrm{p}$ value $>0.05$

Table 3 Comparison of SGOT and SGPT Levels

\begin{tabular}{ccccc}
\hline Groups & $\begin{array}{c}\text { Initial } \\
\text { Mean } \pm \mathbf{S D}(\mathbf{U} / \mathbf{L})\end{array}$ & $\begin{array}{c}\mathbf{2 4 - 4 8} \text { Hours } \\
\mathbf{M e a n} \pm \mathbf{S D}(\mathbf{U} / \mathbf{L})\end{array}$ & $\begin{array}{c}\Delta \\
(\mathbf{U} / \mathbf{L})\end{array}$ & p Value \\
\hline Control & & & & \\
SGOT & $22.60 \pm 5.32$ & $19.53 \pm 3.44$ & -3.07 & 0.69 \\
SGPT & $21.00 \pm 6.55$ & $18.66 \pm 5.40$ & -2.34 & 0.10 \\
Treatment & & & & \\
SGOT & $22.20 \pm 6.37$ & $20.46 \pm 4.53$ & -1.74 & 0.22 \\
SGPT & $22.33 \pm 9.42$ & $19.80 \pm 9.25$ & -2.53 & 0.00 \\
\hline
\end{tabular}

Paired t test, $\mathrm{p}$ value $>0.05$

\section{Discussion}

Kerokan has hepatoprotective activity as it activates heme oxygenase- 1 that plays a vital role to fight oxidative stress., ${ }^{2,3}$ SGOT and SGPT could be indicators of kerokan's effect on liver function. This present study showed that there was no significant difference ( $p>0.05$ ) in mean levels of SGOT and SGPT between control group and treatment group both in initial level and after 24-48 hours.

Based on previous studies, the kerokan has been proved to have the hepatoprotective effect that increases heme oxygenase- $1.0^{2,5,10}$ The heme oxygenase-1 itself is a cytoprotective enzyme that catabolizes heme into biliverdin, carbon monoxide, and ferritin. ${ }^{5}$ Bilirubin and biliverdin are antioxidants and antioxidative stress. Carbon monoxide prevents ischemia and liver reperfusion injury through the p38 MAP kinase pathway. Meanwhile, ferritin increases the ATPase pump to release $\mathrm{Fe}^{2+}$ from the cytosol.

According to researchers point of view, the hepatoprotective effect of the heme oxygenase-1 occurs on damaged or injured liver cells (necrosis) as a result of the hepatitis B virus infection. In normal condition, heme oxygenase-1 will remain increased after kerokan therapy. The results of 
Table 4 Comparison of SGOT and SGPT Levels between Control and Treatment Group

\begin{tabular}{lcccccc}
\hline \multirow{2}{*}{ Groups } & \multicolumn{2}{c}{ SGOT } & \multicolumn{3}{c}{ SGPT } \\
\cline { 2 - 7 } & Mean \pm SD (U/L) & $\Delta(\mathbf{U} / \mathbf{L})$ & p Value & Mean \pm SD (U/L) & $\Delta(\mathbf{U} / L)$ & p Value \\
\hline Initial & & & & & & \\
$\quad$ Control & $22.60 \pm 5.32$ & -0.4 & 0.85 & $21.00 \pm 6.55$ & 1.33 & 0.65 \\
$\quad$ Treatment & $22.20 \pm 6.37$ & & & $22.33 \pm 9.42$ & & \\
$24-48$ hours & & 0.93 & 0.53 & & 1.13 & 0.68 \\
Control & $19.53 \pm 3.44$ & & & $18.66 \pm 5.40$ & & \\
$\quad$ Treatment & $20.46 \pm 4.53$ & & & $19.80 \pm 9.25$ & & \\
\hline
\end{tabular}

Unpaired $t$ test, $p$ value $>0.05$

this study were in line with Kwong et al. ${ }^{3}$, who did a similar study on healthy mice. The results showed that heme oxygenase-1 increased after kerokan therapy with the highest peak of 36 hours.

Immune response resulting in the damaged liver cells did not occur in patients with inactive carrier-chronic hepatitis B. If the immune response is not active, the necrosis does not occur. However, the virus remains making replication without showing clinical symptoms of damaged liver cells (necrosis). It assumed as an answer of to why no hepatoprotective effect found after kerokan therapy on patients with inactive carrierchronic hepatitis B. The results of this study were in line with Chan et al. ${ }^{11}$ They proved that there were no significant changes in liver function after kerokan therapy was applied.

\section{Conclusion}

There was no significant difference in the mean levels of SGOT and SGPT between control and treatment group. It possible because the liver cells of inactive carrier and chronic hepatitis B patients were not damaged (necrosis) after kerokan therapy, and the levels of SGOT and SGPT were still in the normal range.

\section{Conflict of Interest}

There is no conflict of interest at all authors.

\section{Acknowledgments}

The Dental Nursing Study Program and the Nursing Study Program of Politeknik Kesehatan Kementerian Kesehatan Palembang supported this study.

\section{References}

1. Nielsen A, Kaptchuk TJ. Gua sha: a traditional technique for modern practice. $2^{\text {nd }}$ Edition. London: Churchill Livingstone; 2013.

2. Chan ST, Yuen JWM, Gohel MDI, Chung $\mathrm{CP}$, Wong HC, Kwong KK. Guasha-induced hepatoprotection in chronic active hepatitis B: a case study. Clin Chim Acta. 2011;412(1718):1686-8.

3. Kwong KK, Kloetzer L, Wong KK, Ren JQ, Kuo $\mathrm{B}$, Jiang $\mathrm{Y}$, et al. Bioluminescence imaging of heme oxygenase-1 upregulation in the Gua Sha procedure. J Vis Exp. 2009;(30):1385.

4. Wang G, Hamid T, Keith RJ, Zhou G, Partridge CR, Xiang X, Kingery JR, et al. Cardioprotective and antiapoptotic effects of heme oxygenase-1 in the failing heart. Circulation. 2010;121(17):1912-25.

5. Pae HO, Chung HT. Heme oxygenase-1: its therapeutic roles in inflammatory diseases. Immune Netw. 2009;9(1):12-9.

6. Origassa CST, Câmara NOS. Cytoprotective role of heme oxygenase- 1 and heme degradation derived end products in liver injury. World J Hepatol. 2013;5(10):541-9.

7. Ishikawa T. Immunoregulation of hepatitis $B$ virus infection-rationale and clinical application. Nagoya J Med Sci. 2012;74(34):217-32.

8. Soemohardjo S, Gunawan S. Hepatitis B kronik. In: Setiati S, Alwi I, Sudoyo AW, Simadibrata M, Setiyohadi B, Syam AF, editors. Buku ajar ilmu penyakit dalam. $6^{\text {th }}$ Edition. Jakarta: Interna Publishing; 2014. p. $1963-71$.

9. Dahlan MS. Statistik untuk kedokteran dan kesehatan: deskriptif, bivariat, dan multivariat, dilengkapi aplikasi dengan 
menggunakan SPSS. $5^{\text {th }}$ Edition. $3^{\text {rd }}$ Print. Jakarta: Salemba Medika; 2013.

10. Schmidt WN, Mathahs MM, Zhu Z. Heme and HO-1 inhibition of HCV, HBV, and HIV. Front Pharmacol. 2012;3:129.

11. Chan ST, Yuen JWM, Gohel MDI, Wong HC,
Chung CP, Sun Y, et al. Does guasha offer hepatoprotective effect to chronic inactive hepatitis b carriers? A built-in design to control subject expectation. J Altern Complement Med. 2013;19(9):772-6. 